\title{
PEMASARAN RELASIONAL PADA TOKO IJEN DESA CINDOGO, KECAMATAN TAPEN, KABUPAEN BONDOWOSO.
}

\author{
Wira Rizkianingsih $^{1}$, Joko Widodo ${ }^{1}$, Sri Wahyuni ${ }^{1}$ \\ ${ }^{1}$ Program Studi Pendidikan Ekonomi, Fakultas Keguruan dan Ilmu Pendidikan, Universitas Jember \\ e-mail: Wierarizki@gmail.com
}

\begin{abstract}
Abstrak
Penelitian ini bertujuan untuk mendeskripsikan pemasaran relasional untuk mempertahankan konsumen pada Toko Ijen Desa Cindogo Kecamatan Tapen Kabupaten Bondowoso. Penelitian ini merupakan penelitian deskriptif dengan pendekatan kualitatif. Subjek dalam penelitian ini adalah pemilik toko Ijen, sedangkan informan penelitian yaitu konsumen dari toko ijen. Metode pengumpulan data yang digunakan yaitu observasi, wawancara dan dokumentasi. Analisis data yang digunakan yaitu reduksi data, penyajian data dan verifikasi data. Hasil penelitian ini menunjukkan bahwa Pemasaran Relasional pada Toko Ijen Desa Cindogo Kecamatan Tapen Kabupaten Bondowoso memiliki empat aspek dalam Pemasaran Relasional. Pemasaran Relasional yang dilakukan oleh toko Ijen yang Pertama adalah ikatan, Ikatan yang dilakukan oleh pemilik toko kepada konsumen, memberikan jika konsumen mau berhutang. Kedua kepedulian, kepedulian yang diberikan pemilik toko, Menginformasikan jauh-jauh hari jika toko tidak buka. Ketiga Hubungan Jangka Panjang, hubungan yang diberikan kepada konsumen, mengadakan tasyakuran bersama dengan konsumen. Keempat kepercayaan yang diberikan adalah, memberikan barang yang masa kadaluarsanya masih lama. dengan adanya keempat elemen tersebut membuat konsumen akan semakin loyal dengan barang yang diual di tempat tersebut. Dengan adanya pemasaran relasional yang dilakukan oleh pemilik toko Ijen mampu mempertahankan pelanggan sehingga toko Ijen mampu bertahan ditengah persaingan dengan toko-toko lain meskipun banyak yang menjual barang sejenis.
\end{abstract}

Kata Kunci: Pemasaran Relasional

\section{PENDAHULUAN}

Di era globalisasi, pertumbuhan ekonomi semakin pesat. Laju pertumbuhan ekonomi yang semakin pesat membuat tingkat persaingan semakin ketat, khususnya pada usaha dagang. Faktor utama yang mempengaruhi hal ini adalah tingkat kebutuhan manusia semakin meningkat dari waktu ke waktu. Hal ini menjadi peluang bagi pelaku usaha dagang dalam berlomba-lomba memasarkan produknya. Pelaku usaha dagang harus memiliki kompetensi yang mumpuni agar tetap dapat bertahan ditengah ketatnya persaingan. Untuk menghadapi persaingan ini, pelaku usaha dagang harus memiliki perencanaan yang matang serta trik untuk membuat konsumen selalu ingin berbelanja di toko tersebut serta merasa paling nyaman berbelanja di toko tersebut.

Tujuan pemasaran adalah mengenal dan memahami pelanggan sedemikian rupa hingga produk yang dijual akan sesuai dengan keinginan pelanggan, sehingga produk tersebut dapat terjual. Idealnya pemasaran menyebabkan pelanggan siap membeli sehingga yang harus difikirkan selanjutnya adalah bagaimana membuat produk tersebut tetap tersedia. Menurut Kotler dan Amstrong (2001:304), pemasaran relasional meliputi hal mempertahankan, menciptakan dan mendorong suatu hubungan erat dengan para pelanggan dan semua pihak yang berkepentingan. Lama kelamaan pemasaran akan semakin bergeser dari fokus transaksi individual menjadi berfokus pada transaksi menjalin hubungan yang membangun nilai tinggi menjadi jaringan yang memberikan kepuasan. Menurut Kotler (2003) pemasaran relasional adalah pola pikir dari sebuah gerakan yang semata-mata berlandaskan pada konflik dan kompetisi menuju ke arah pemikiran yang berlandaskan suatu hubungan yang saling ketergantungan yang bekerjasama untuk saling menguntungkan.

Dari berbagai definisi yang telah dikemukakan di atas, dapat ditarik sebuah kesimpulan bahwa pemasaran relasional adalah metode yang digunakan dalam mengelola antara hubungan jangka panjang melalui komunikasi efektif dan efisien antara perusahaan dengan pelanggan untuk mencapai tujuan pemasaran itu sendiri. 


\section{METODE PENELITIAN}

Penelitian ini menggunakan jenis penelitian deskriptif dengan pendekatan kualitatif. Dalam peneliti ini, penentuan lokasi penelitian menggunakan metode purpose area .Yaitu lokasi penelitian secara sengaja telah ditentukan oleh peneliti. Lokasi penelitian yang dipilih oleh peneliti adalah Pemasaran Relasional di Desa Cindogo, Kecamatan Tapen Kabupaten Bondowoso. Pada peneliti ini, teknik penentuan subjek dan informan penelitian menggunakan tehnik purposive sampling. Penggunaan teknik ini di dasarkan pada pertimbangan-pertimbangan tertentu atau secara sengaja sudah ditentukan dengan alasan akan memberikan informasi yang dibutuhkan oleh peneliti.

Subjek dalam penelitian ini adalah pemilik toko Ijen Desa Cindogo, Kabupaten Bondowoso. Selanjutnya yang menjadi informan tambahan dalam penelitian ini adalah beberapa konsumen yang berbelanja di Toko Ijen. Metode pengumpulan data yang digunakan terdiri dari metode wawancara, observasi, dan dokumentasi. Analisis data yang digunakan yaitu reduksi data, penyajian data, dan penarikan kesimpulan.

\section{HASIL DAN PEMBAHASAN Hasil Penelitian}

Pemasaran relasional adalah pemasaran yang dilakukan oleh usaha dagang yang dapat menarik dan mempertahankan konsumen dengan cara yang dimiliki oleh pemilik toko Ijen.

Hasil penelitian yang didapat dilapangan mengenai Pemasaran Relasional pada Toko Ijen Desa Cindogo Kecamatan Tapen Kabupaten Bondowoso menggunakan 4 aspek yang di lakukan, yaitu:

1. Ikatan

Ikatan yang dilakukan antara pemilik dengan konsumen dimana pemilik dengan konsumen harus saling ketergantungan antara kedua belah pihak yang harus sama-sama kuat supaya hubungan keduanya dapat bertahan lama. jika seorang pelanggan memiliki rasa ketergantungan yang kurang kuat maka pelanggan tersebut akan pindah dan berganti pemasok untuk memenuhi kebuthannya.

Alasan utama dalam pemasaran relasional adalah memiliki suatu ikatan, ikatan yang dimiliki antara pemilik dengan konsumen akan menumbuhkan rasa ketergantungan antara kedua belah pihak. Pemilik melakukan cara tersendiri supaya konsumen merasa nyaman datang ke tempat tersebut, selalu memberikan kepercayaan kepada konsumen dalam transaksi jual beli atau diluar transaksi jual beli, selalu memberikan hutang kepada konsumen yang sudah lama berlangganan dan tidak pernah menepati janjinya.

Berikut hasil wawancara dengan SJ selaku informan utama dalam penelitian ini. Berikut jawaban dari SJ:

"Ikatan yang terjadi antara saya dengan konsumen, kalau ada yang mau berhutang saya kasih jika sudah lama langganan. selalu memberikan kepercayaan kepada konsumen dalam transaksi jual beli serta diluar transaki jual beli.Saya harus selalu mengerti kemauan konsumen supaya konsumen akan kebali lagi untuk berbelanja disini. Harus pintar-pintar ngambil hati konsumen saya biar ia tertarik untuk datang lagi, "'(SJ.52Th)

Ikatan menyebabkan ketergantungan antara kedua pihak yaitu pemilik dengan konsumen, dimana konsumen merupakan salah satu aset yang harus diaga demi kemajuan suatu usaha yang sedang di kelola. Konsumen akan merasa nyaman jika barang yang ia butuhkan selalu tersedia di tempat tersebut, terlebih lagi di tempat tersebut bisa berhutang dan konsumen merasa paling nyaman berbelanja ditempat tersebut.

\section{Kepedulian}

Kepedulian yang harus dimiliki oleh pemilik Toko terhadap pelanggan adalah memperhatikan sudut pndang pelanggan dalam mengatasi masalah yang dialami. Selalu memberikan keuntungan bagi kedua belah pihak yaitu dengan pendekatan diri kepada pelanggan maka dapat diketahui penjual mampu mengetahui keinginan serta kebutuhan pelanggan.

Alasan lain yaitu dengan melakukan kepedulian dimana pemilik harus bertanggung jawab penuh terhadap barang serta yang berkaitan dengan Toko misalnya pelayanan yang diberikan kepada konsumen. Memperhatikan permasalahan yang terjadi dalam proses transaksi, misalnya dalam 
memberikan barang kepada konsumen, harus memberikan barang yang sesuai dengan harapan konsumen, konsumen dapat mengembalikan barang yang dibeli jika tidak sesuai dengan keinganannya, misalnya jika masa kadaluarsanya hampir habis. Menginformasikan kepada konsumen jika toko sedang tidak buka, supaya konsumen tidak merasa kecewa.

Seperti yang disampaikan oleh SJ selaku informan utama dalam penelitian ini:

"Selalu menanyakan jika lama tidak berbelanja, menginformasikan jauh-jauh hari jika toko saya tidak buka, memberikan produk yang sesuai dengan konsumen butuhkan, serta misalkan ada konsumen saya membeli dan sudah masuk masa kadaluarsa bisa dikembalikan dan diganti dengan yang baru." (SJ.52th)

Setiap konsumen memiliki hak dan keinginannya tersendiri untuk menentukan barang apa saja yang ia butuhkan serta ia inginkan, dan dimana ia akan membeli barang ia butuhkan, terlebih lagi konsumen merasa nyaman apabila merasa diperhatikan oleh seorang pemilik Toko, apalagi pemilik Toko merasa sangat peduli bukan hanya saat melakukan transaksi jual beli, bentuk kepedulian yang lain yang dilakukan oleh pemilik adalah memberikan parsel kepada konsumen yang selalu melakukan peroses pembelian secara terus menerus di tempat tersebut.

3. Hubungan jangka panjang

Hubungan jangka panjang haruslah saling memberi dan menerima. Artinya baik penjual atau pelanggan sama-sama akan mendapatkan keuntungan. Pelanggan yang menginginkan diskon besar, tentunya harus mengimbangi dengan pembayaran langsung atau tunai.

Selain memberikan kepedulian terhadap konsumen pemilik Toko Ijen harus selalu menjaga hubungan baik dengan semua kosumen, apalagi dalam usaha perdagangan diperlukan hubungan jangka panjang supaya antara pemilik toko dengan konsumen sama-sama mendapatkan keuntungan. Hubungan jangka panjang terjadi karena adanya rasa saling percaya antara pemilik dengan konsumen, serta menjaga komunikasi dengan baik kepada konsumen serta melakukan komunikasi diluar proses transaksi jual beli, misalnya mengundang konsumen untuk sekedar datang ke acara arisan.

Seperti yang disampaikan oleh SJ selaku informan utama dalam penelitian ini:

"Memberikan pelayanan yang baik, memberikan diskon apalagi dalam pembelian yang cukup banyak dan langsung membayar. jika pelanggan saya sudah lama tidak berbelanja atau mempunyai produk baru pasti saya hubungi, menjaga komunikasi yang baik, kalau diluar transaksi biasanya saya mengajak konsumen untuk mengikuti arisan barang di toko saya mbak." (SJ.52th)

Konsumen juga menjaga hubungan baik dengan pemilik toko, bukan hanya pemilik toko yang menjaga hubungan baik, akan tetapi konsumen juga menjaga hubungan baik, karena konsumen juga merasakan jika tempat tersebut sudah cocok dan enak, maka ia tidak akan mau berpindah ketempat lain, meskipun orang lain mengajak ke tempat yang menjual barang sejenis. Konsumen menjaga hubungan baik dengan dengan pemilik toko yaitu dengan cara selalu berbelanja di tempat tersebut.

4. Kepercayaan

Selain memberikan hubungan jangka panjang, pemilik Toko Ijen juga memberikan kepercayaan kepada konsumen. kepercayaan akan terjalin jika antara konsumen dengan pemilik toko sama-sama merasa saling mengenal dan berhubungan baik. Pemilik toko selalu memberikan kepercayaan kepada konsumennya. memberikan kepercayaan terhadap konsumen yaitu dengan cara, jika ada konsumen yang sudah lama berlangganan di Toko Ijen dan ingin berhutang maka pemilik mengijinkan jika memang konsumen tersebut benar-benar sudah lama berlangganan dan tidak berbelanja di tempat lain, asalkan antara penjual dengan pembeli memiliki kesepakatan terlebih dahulu, jika konsumen melanggar kesepakatan tersebut maka pemilik Toko Ijen tidak akan mengijinkan lagi. serta memberikan kepercayaan kepada konsumen bahwa produk yang dijual di Toko Ijen memiliki masa kadaluarsa yang cukup lama. berikut:

Hal ini sesuai dengan pernyataan yang disampaikan oleh pemilik Toko Ijen adalah sebagai

"Ya memberikan mbak, kalau pelanggan itu sudah lama dan selalu berbelanja di tempat 
saya, bisa dibilang tidak pernah ketempat lain. Yang paling penting pelanggan itu sudah saya percayai. Misalkan aja berjanji membayar tanggal sekian, jadi ya harus tanggal sekian sudah bayar mbak. konsumen juga percaya bahwa produk yang saya jual pasti masa kadaluarsanya lama, kalo sudah hampir saya kasih diskon mbk "(SJ.52th)

konsumen selalu menginginkan produk yang sesuai dengan keinginan mereka, dan barang yang dibeli oleh konsumen mempunyai bermacam-macam jenis dan selalu membeli dengan jumlah yang cukup banyak, maka konsumen tersebut mengaku selalu berhutang kepada pemilik dan selalu di ijinkan oleh pemilik, dengan ada kesepakatan terlebih dahulu.

Tabel 4.2 Perbedaan Toko Ijen dengan Toko Lain

\begin{tabular}{rll}
\hline No. & Toko Ijen & Toko Lain \\
\hline $\begin{array}{l}\text { 1. } \\
\text { Bermacam barang dari mulai kebutuhan } \\
\text { anak-anak sampai orang dewasa. }\end{array}$ & $\begin{array}{l}\text { Kebanyakan kebutuhan orang dewasa } \\
\text { saja. }\end{array}$ \\
\hline 2. & Harga barang dagangan relatif murah & Relatif mahal \\
\hline 3. & Bisa berhutang/membayar separuh & Tidak bisa membayar separuh-separuh \\
\hline 1. & Terdaftar sebagai pelanggan di Toko & Tidak terdaftar dan tidak memilik data \\
& Ijen/ memiliki data & \\
\hline 2. & Bisa memesan barang terlebih dahulu & Tidak bisa \\
\hline
\end{tabular}

\section{Pembahasan}

Hasil penelitian yang didapat dilapangan mengenai Pemasaran relasional terdapat 4 aspek yang ada pada Toko Ijen Desa Cindogo Kecamatan Tapen Kabupaten Bondowoso adalah sebagai berikut:

Sesuai hasil penelitian yang telah dikemukakan diatas, dapat diketahui bahwa usaha toko Ijen di Desa Cindogo Kecamatan Tapen telah menggunakan beberapa aspek pemasaran relasional tersebut, yang di antaranya adalah memberikan dampak yang cukup baik terhadap majunya usaha Toko Ijen. Salah satu yang diberikan oleh Toko Ijen ialah: memberikan ikatan antara pemilik Toko Ijen dengan konsumen, memberikan rasa kepedulian terhadap konsumen, memberikan hubungan jangka panjang terhadap konsumen serta memberikan kepercayaan terhadap konsumen.

Toko Ijen merupakan usaha dagang yang awalnya hanya sebuah Toko kecil yang menjual sedikit produk, kemudian tahun demi tahun usaha dagang ini berkembang karena keuletan dari pemilik Toko Ijen. Dari keuletan tersebut Toko Ijen menjadi usaha dagang yang sangat maju dan cukup besar serta mempunyai cukup banyak pelanggan, dari yang awalnya hanya toko yang menjual eceran sampai menjadi toko besar dan bisa menjual grosir yang melayani banyak pelanggan. pelanggan Toko Ijen tidak hanya dari daerah cindogo saja melainkan dari berbagai kalangan. Pemilik Toko Ijen harus memiliki cara supaya konsumen Toko Ijen selalu merasa nyaman untuk berbelanja di tempat tersebut dan tidak berpindah ke tempat lain meskipun tempat lain mempunyai barang yang sama, karena konsumen adalah aset terbesar untuk kemajuan usaha yang sedang dikelola.

Konsumen dan pemilik Toko Ijen memiliki ikatan yang sangat kuat terhadap konsumen Toko Ijen, apalagi terhadap pelanggan tetap. Karena antara pemilik dengan konsumen Toko Ijen mempunyai rasa ketergantungan. Pemilik Toko Ijen mempunyai ikatan dengan konsumen yaitu dengan cara memberikan hutang kepada konsumen jika sudah lama berlangganan, memberikan ikatan persaudaraan dan pertemanan antara konsumen dengan pemilik, memberikan harga yang relatif murah, menyediakan barang yang diinginkan oleh konsumen. Hal ini sesuai dengan pendapat Marsudi (2004:1) ikatan adalah semua aktivitas pemasaran untuk mengikat pelanggan bahwa produk yang ditawarkan atau dikonsumsi adalah satu-satunya solusi yang dibutuhkan pelanggan sehingga pelanggan tidak pindah (migrate) ke produk lain.

Pemilik Toko Ijen mempunyai Kepedulian untuk bisa mempertahankan pelanggan dengan caranya sendiri. Pemilik Toko Ijen selalu memperhatikan pelanggannya dengan cara menanyakan jika lama tidak berbelanja di Toko Ijen dan memberikan produk sesuai dengan keinginan konsumen. Hal ini sesuai dengan pendapat Tjiptono (2008), empati adalah kesediaan perusahaan untuk memahami masalah pelanggan, serta memberikan perhatian personal kepada para pelanggan dan memiliki jam 
operasi yang nyaman. Kepedulian antara pemilik Toko Ijen dengan konsumen Toko Ijen harus selalu terjaga dengan baik, agar selalu tercipta komunikasi yang baik dan menjalin hubungan yang baik.

Pemilik Toko Ijen harus mempunyai suatu hubungan baik dengan konsumen dimana hubungan itu harus tetap terjaga dengan baik, apalagi dalam hubungan jangka panjang, hubungan tersebut harus tetap dijaga bukan karena hanya dalam transaksi jual beli, akan tetapi dalam kehidupan sehari-hari juga misalnya mengadakan tasyakuran, hubungan tersebut harus dibina dengan baik antara konsumen dengan pemilik Toko karena keduanya mempunyai keuntungan yang bisa membuat usaha dagang mereka semakin meningkat. Hal ini sesuai dengan pendapat Barnes (2003:32) membina hubungan jangka panjang antara perusahaan dengan pelanggan merupakan fokus utama penerapan pemasaran relasional. pemilik Toko harus selalu membina hubungan baik dengan konsumen agar dapat terjaga usaha yang sedang dikelola. Cara menjaga hubungan baik dengan pelanggan yaitu selalu memberikan pelayanan yang baik, selalu mengabarkan jika ada produk baru dan ada diskon di toko Ijen.

Selain hubungan jangka panjang pemilik toko Ijen harus menumbuhkan rasa percaya atau kepercayaan antara pemilik dengan konsumen toko Ijen. Masing-masing pihak antara konsumen Toko Ijen dengan pemilik toko harus memiliki komitmen yang cukup kuat, konsumen tidak mudah terpengaruh oleh pihak lain atau pedagang lain meskipun ditawarkan barang dagang yang sejenis. Konsumen tersebut tetap akan berbelanja di toko Ijen karena sudah merasa nyaman dan percaya bahwa produk yang di jual di toko Ijen sudah sesuai dengan keinganan dan manfaat yang dibutuhkan oleh konsumen. Hal ini sesuai dengan pendapat Mowen dan Minor (2001), kepercayaan pelanggan adalah semua pengetahuan yang dimiliki oleh pelanggan dan semua kesimpulan yang dibuat pelanggan tentang objek, atribut, dan manfaatnya.

Produk yang dijual di Toko Ijen mempunyai harga yang lebih murah dibandingkan dengan Toko lainnya, hal tersebut yang membuat konsumen toko Ijen ingin selalu berbelanja di toko Ijen. Hal inilah yang membuat konsumen toko Ijen menjadi pelanggan setia di Toko tersebut. Hal tersebut sesuai dengan pendapat yang disampaikan oleh Olson dalam Trisno Mushanto, (2004:124) bahwa loyalitas pelanggan merupakan dorongan perilaku untuk melakukan pembelian secara berulang-ulang dan untuk membangun kesetiaan pelanggan terhadap suatu produk maupun jasa yang dihasilkan oleh Toko Ijen tersebut yang membutuhkan waktu yang lama melalui proses pembelian yang terjadi secara berulang-ulang.

Toko Ijen mempunyai pelanggan yang cukup banyak.pelanggan sudah percaya dengan barang yang dijual di Toko Ijen. Barang yang dijual kepada konsumen memiliki masa kadaluarsa yang masih lama. jika tersedia barang yang ada di Toko Ijen dan memiliki masa kadaluarsa yang sedikit maka pemilik Toko Ijen biasanya menjual dengan harga yang lebih murah lagi. Konsumen Toko Ijen melakukan pembelian sedikitnya sebulan dua kali untuk memenuhi kebutuhan hidupnya. Banyak sekali konsumen toko Ijen melakukan pemebelian secara berulang-ulang dan terus menerus. Hal ini membuat toko Ijen mempunyai pelanggan tetap karena sudah mengenal dan percaya dengan produk yang dijual di toko Ijen. hal tersebut yang membuat penjual dan konsumen mempunyai komunikasi yang baik dan menumbuhkan rasa kesetiaan terhadap toko Ijen.

Keempat dimensi diatas memberikan dampak positif terhadap SJ selaku pemilik Toko Ijen. beliau memiliki pelanggan yang sangat banyak. Selain itu juga menciptakan kesetiaan konsumen terhadap Toko Ijen. loyalitas konsumen dapat terlihat saat konsumen berbelanja di tempat tersebut. Banyak diantara mereka memilih untuk membeli di Toko Ijen meskipun banyak pertokoan lainnya yang menjual barang serupa.

\section{PENUTUP}

Pemasaran relasional yang digunakan oleh Pemilik Toko Ijen Desa cindogo Kabupaten Bondowoso untuk dapat mempertahankan Konsumen yakni Pertama adalah ikatan. Ikatan yang dilakukan oleh pemilik toko kepada konsumen adalah: memberikan pelayanan yang baik, memberikan harga yang relatif murah, memastikan barang yang dibutuhkan oleh konsumen selalu tersedia di toko tersebut, membentuk arisan antara pemilik dengan konsumen supaya menjalin hubungan jangka panjang diluar transaksi jual beli, memberikan jika konsumen mau berhutang di 
toko tersebut. Hal ini dilakukan untuk membuat konsumen nyaman berbelanja di tempat tersebut dan ingin terus menerus berbelanja. Yang kedua adalah kepedulian, kepedulian juga digunakan oleh toko Ijen untuk mempertahankan pelanggan. Kepedulian yang diberikan pemilik toko adalah: Menginformasikan jauh-jauh hari jika toko tidak buka, boleh mengembalikan atau menukar jika produk yang dibeli tidak sesuai atau memasuki masa kadaluarsa, menanyakan barang apa saja yang banyak terjual serta selalu tepat waktu untuk membuka toko. Ketiga adalah hubungan jangka panjang yang diberikan kepada konsumen: Memberikan diskon kepada konsumen, menghubungi konsumen jika sudah lama tidak berbelanja, mengabarkan konsumen jika ada produk baru, mengadakan tasyakuran bersama dengan konsumen. Keempat adalah kepercayaan, kepercayaan yang diberikan adalah: mengijinkan jika konsumen mau berhutang, memberikan barang yang masa kadaluarsanya masih lama serta merekomendasikan Toko Ijen kepada Orang-orang yang belum mengetahui. Yang kelima yaitu loyalitas pelanggan, dimana jika keempat elemen diatas sudah berjalan maka loyalitas pelanggan akan dengan sendirinya muncul, karena loyalitas pelanggan merupakan bagian dari keempat aspek tersebut.

Berdasarkan hasil dari kesimpulan penelitian ini maka dapat diberikan saran kepada pemilik Toko Ijen Desa Cindogo Kecamatan Tapen Kabupaten Bondowoso, lebih memberikan pelayanan yang baik, serta selalu menjaga hubungan baik terhadap konsumen supaya konsumen tidak berpindah ketempat lain, serta selalu memberikan kepedulian terhadap konsumennya.

\section{DAFTAR PUSTAKA}

Barnes, J. G. 2003. Secrets of customer Relationship Manajement, Alih Bahasa Andreas winardi. Yogyakarta: Penerbit Andi.

Marsudi. B Utomo. 3 Kunci Marketing Pengikat Hati Pelanggan. www.kammi-jepang .net (diakses pada tanggal 14 Januari 2009)

Mowen, J.C dan M. Minor. 2001. Perilaku Konsumen, Jilid I.Jakarta: Penerbit Erlangga.

Tjiptono, F. 2008. Service Management. Yogyakarta: Andi. 